\title{
ACUTE PANCREATITIS IN PREGNANCY - FROM ETIOPATHOGENESIS TO THERAPY
}

\author{
Snežana Tešić-Rajković1,2, Biljana Radovanović-Dinić1,2
}

\begin{abstract}
Acute pancreatitis (AP) in pregnancy is a relatively rare disease, but at the same time a great challenge for any physician, since it poses a potential threat to both the mother and the fetus. The occurrence of this serious disease requires multidisciplinary efforts in both the diagnosis and treatment, with the involvement of gynecologists, gastroenterologists and surgeons. AP is more frequent in the third trimester and postpartum period. Pregnancy has long been considered as a possible cause of acute pancreatitis. However, more recent studies have shown that in pregnancy the main causes for the development of AP are gallstones or hyperlipidemia, accounting for a higher incidence of this disease in pregnant women. The diagnosis of acute pancreatitis in pregnancy can be a challenge for the clinician, since the clinical manifestations may resemble various pregnancy complications, such as hyperemesis gravidarum, placental abruption, or ruptured ectopic pregnancy. Treatment strategy involves an assessment of both maternal and fetal risks. During severe AP, when there is single or multiple organ failure, emergency childbirth may be necessary. There have been no standardized recommendations for delivery for women with AP in their third trimester in order to reduce maternal and neonatal morbidity and mortality. Larger clinical studies are required for the formulation of recommendations for the diagnosis, follow-up of the clinical course, and treatment of AP in pregnant women.
\end{abstract}

Acta Medica Medianae 2020;59(3):41-47.

Key words: pancreatitis, pregnancy, diagnosis, therapy

${ }^{1}$ University of Niš, Faculty of Medicine, Niš, Serbia

${ }^{2}$ Clinic of Gastroenterology and Hepatology, Clinical Centre Niš, Serbia

Contact: Snežana Tešić-Rajković

81 Dr Zoran Djindjić Blvd., 18000 Niš, Serbia

E-mail: snezana.tesic.rajkovic@medfak.ni.ac.rs

\section{Introduction}

Pregnancy is a specific physiological condition of a women in her reproductive age of life which runs without any complications in over $80 \%$ of cases. Acute pancreatitis (AP) in pregnancy is a relatively rare disease, but at the same time a great challenge for any physician, since it poses a potential threat to both the mother and the fetus. The occurrence of this serious disease requires multidisciplinary efforts in both the diagnosis and treatment.

\section{Epidemiology}

AP occurs in $0.03-0.09 \%$ of pregnancies (1). The incidence of AP in pregnancy has been reported to be as high as $1 / 1000$ (2). AP is more frequent in the third trimester and postpartal period (3). If it occurs during the first trimester, AP is associated with a higher proportion of fetal complications and mortality, and should be taken very seriously in that period of pregnancy (3).

AP in pregnancy may present as a mild, selflimited disease, but more serious forms may develop as well, with local and distant complications, possibly causing the death of both the mother and the fetus (1). Maternal and/or fetal death rates have been markedly reduced thanks to the currently employed diagnostic methods and appropriate and timely therapy (1). Some recent studies have shown that maternal mortality caused by AP is below $1 \%$, but fetal death rates are still rather high $-6.6 \%(4$, 5 ). In pregnant women with AP preterm births (before gestational weeks 37 or 32 ) are more common, as well as respiratory distress syndrome and jaundice in their premature infants. Fetal morbidity and mortality are solely the consequence of premature birth (6). In term infants, morbidity and mortality rates have not been reported to be increased. 


\section{Ethiopathogenesis}

Pregnancy has long been considered as a possible cause of acute pancreatitis. However, more recent studies have shown that in pregnancy the main causes for the development of AP are gallstones or hyperlipidemia, accounting for a higher incidence of this disease in pregnant women (7).
The most common cause of AP in pregnancy are gallstones, in about $70 \%$ of cases (4). Other possible etiological factors (Table 1) are alcohol intake, metabolic diseases, medicaments, traumas, medical interventions, infections, vascular disorders (ischemia), genetic factors (trypsinogen gene mutation), systemic diseases, structural anomalies, tumors, insect bites and other, still unrecognized factors $(8,9)$.

Table 1. Etiology of AP in pregnant women

\begin{tabular}{||ll||}
\hline - & Gallstones \\
- & Alcohol \\
- & Dypertriglyceridemia \\
- & Acute fatty liver in pregnancy \\
- & Pre-eclampsia \\
- & Medical interventions \\
- & Infections \\
- & Genetic factors (trypsinogen gene mutation) \\
- & Systemic diseases \\
- & Structural anomalies \\
- & Tumors \\
- & Insect bites \\
- & Unrecognized etiological factors \\
\hline
\end{tabular}

Gallstones are the most commonly identified etiological factor in the occurrence of AP in pregnancy, similarly as in the rest of (mostly female) population (10). During pregnancy, there are factors predisposing to the development of biliary calculi, such as increased body weight and hormonal changes. Gallbladder volume increases in pregnancy and biliary flow is reduced (10). Cholesterol is increased in the bile in relation to bile acids and phospholipids, which may result in the retention of cholesterol crystals and creation of gallstones. Increased estrogen levels in pregnancy may lead to biliary stasis (10). Increased progesteron levels induce the relaxation of smooth muscles in the gallbladder wall, which increases the pressure at the sphincter of Oddi level, which contributes to biliary stasis.

Hypertriglyceridemia in pregnancy may lead to the development of AP. The level of serum triglycerides exceeding $11 \mathrm{mmol} / \mathrm{L}$ may induce an acute pancreatitis attack. In pregnancy, the levels of triglycerides normally rise gradually, especially during the second and third trimester. AP usually occurs in women who had hypertriglyceridemia even before pregnancy (11). Familial hypertriglyceridemia can be 42 further complicated with AP in pregnancy. However, triglyceride values and the severity of clinical picture of AP are not correlated. Hypercholesterolemia is not associated with acute pancreatitis; $10-50 \%$ of AP in pregnancy are associated with hypertriglyceridemia (12). AP caused by hypertriglyceridemia in pregnancy tend to be more serious and associated with a higher risk of complications (organ dysfunction, shock, infections) $(5,12,13)$. Treatment of hypertriglyceridemia in pregnancy in order to prevent AP is complex and challenging, since it has been found for many lipid-lowering drugs that they cannot be safely used in pregnancy. The patients with hypertriglyceridemia usually also have multiple risk factors, such as diabetes, alcohol consumption, and hypothyroidism, which further complicates their therapeutic management (14).

Hyperparathyroidism and hypercalcemia are relatively infrequent causes of acute pancreatitis. Hyperparathyroidism is rare in pregnancy and is most commonly the consequence of parathyroid adenoma (15). Acute pancreatitis occurs as the consequence of hypercalcemia, which may also cause hyperemesis gravidarum, hypertension, pre-eclampsia, nephrolithiasis, muscle weakness, and even 
hypercalcemic crisis. Fetal complications usually include postpartal hypocalcemia, low birth weight, preterm birth and fetal death. A timely diagnosis and adequate therapeutic management may improve the outcome, and in cases of unclear AP etiology it is necessary to take into consideration as well this possible cause of the disease (4).

Acute fatty liver in pregnancy (AFLP) is a rare disorder, described for the first time as a specific clinical entity by Sheehan in 1940. AFLP usually occurs in the third trimester and clinically manifests with nausea, vomiting, moderate enzyme elevation, development of coagulopathy, hyperfibrinogenemia, hypoglycemia and hyperbilirubinemia. Acute pancreatitis develops as a complication of this very serious condition and is life-threatening to the pa-tient. Development of a pseudocyst with secondary infections or hemorrhagic pancreatitis with retroperitoneal bleeding present a special problem in patients with already developed coagulopathy. Serial monitoring of serum lipase and amylase levels several days after the onset of hepatic dysfunction is therefore recommended. Compared to amylase, it appears that serum lipase is more useful in the monitoring of the course of acute pancreatitis. Diagnostic visualization methods (such as magnetic resonance imaging) can be a valuable tool in the diagnosis of pancreatitis and assessment of develop-ment of complications (16).

Pre-eclampsia. A recent study by Haker et al. has demonstrated a significant association of acute pancreatitis in pregnancy with pre-eclampsia (especially severe pre-eclampsia) (6). Pre-eclampsia is associated with microvascular disorders which may involve cerebral, placental, hepatic, renal and splanchnic circulation. Microvascular disorders may lead to the development of pancreatitis (17).

\section{Clinical manifestations}

Based on its clinical course and prognosis, according to the Atlanta classification, AP can be mild, moderate (moderately severe) or severe. Mild AP is the most common form of pancreatitis and it lasts for up to a week. It is characterized by the absence of any significant damage to the pancreas and development of local or systemic complications. Moderately severe AP is defined by the presence of transient organ failure (lasting for less than 48 hours) and/or local or systemic complications without any persistent organ failure or aggravation of comorbidities. Severe AP is defined by persistent single or multiple organ failure (MODS), i.e. organ failure lasting for more than 48 hours (Table 2) (18).

Table 2. AP severity according to the Atlanta classification

\begin{tabular}{||l||l||}
\hline Mild AP & absence of organ failure and complications \\
\hline Moderately severe AP & transient organ failure $(<48 \mathrm{~h})$ and/or local or systemic complications \\
\hline Severe AP & persistent single or multiple organ failure $(>48 \mathrm{~h})(\mathrm{MODS})$ \\
\hline
\end{tabular}

Acute pancreatitis manifests clinically with unspecific symptoms and signs, which may delay a timely diagnosis. The most common symptom is abdominal pain, occurring suddenly and extending in the form of a "belt" to the back or to the left shoulder and left shoulder blade. The pain is usually accompanied by nausea and vomiting which may represent a reaction to the pain or the consequence of reactive dilation of the stomach due to retroperitoneal spread of the inflammation. The disease is commonly associated with abdominal distension, paralytic ileus and left pleural effusion (19).

Additional complications in pregnant women involve preterm labor, preterm delivery and pregnancy loss $(1,10)$.

A study by Luo et al. with 121 pregnant women with AP has demonstrated the association between the severity of AP and maternal and fetal morbidity and mortality. The group with severe AP had the highest rate of maternal and fetal mortality. It is assumed that in severe AP systemic inflam- matory response can produce generalized endothelial dysfunction, causing further tissue damage (9). A study by Sun et al. reported as well that increased intraabdominal pressure in severe AP was assosiated with a higher risk of fetal death (20).

\section{Diagnosis}

The fundamental criteria for the diagnosis of acute inflammation of the pancreas have been for years abdominal pain and elevated serum amylases. Nowadays, new biochemical diagnostic assays and visualization methods are attracting much attention, although clinical picture of the disease and serum amylases are still important indices in identifying individuals with AP.

According to the revised Atlanta classification, the diagnosis of AP is made on the basis of the presence of two out of three criteria presented in Table 3 (18). 
Table 3. Diagnosis of AP

1. Abdominal pain (acute attack of persistent, strong epigastric pain, frequently extending to the back).

2. Activity of serum lipase (or amylase) increased at least three times related to upper reference cut-off value

3. Characteristic finding of acute pancreatitis on computerized tomography (MSCT) or, less often, magnetic resonance (MR) imaging or transabdominal ultrasonography.

The diagnosis of acute pancreatitis in pregnancy can be a challenge for the clinician, since the clinical manifestations may resemble various pregnancy complications, such as hyperemesis gravidarum, placental abruption or ruptured ectopic pregnancy (21). Physiologic leukocytosis in pregnancy $(<16,000)$ should also be taken into account, which can have an impact on the assessment of AP severity. In normal pregnancy, alkaline phosphatase may be three times as high as normal, which can have an impact on the assessment of etiology (21). A study by Tang et al. has reported normal levels of liver enzymes in over $80 \%$ of pregnant women with biliary AP (1).

A threefold increase of serum amylase and/or lipase is considered to be an acceptable criterion for the diagnosis of AP in pregnant women. Serum lipase has a higher sensitivity and specificity in the diagnosis of AP compared to amylase (21).

Serum amylase values can be normal in severe forms of $A P$ as the consequence of rapid destruction of acinar pancreatic cells, as well as in an acute exacerbation of chronic alcohol-induced pancreatitis due to deficient exocrine pancreatic secretion. In acute pancreatitis and hypertriglyceridemia, false low serum values of amylases may sometimes be obtained (22).

Echosonography of the abdomen is the first visualization procedure used to verify the diagnosis of AP in pregnant women. Furthermore, it is the initial method used to establish the etiology of $A P$, since it is highly sensitive in the detection of biliary stones, follow-up of pregnant women with mild disease forms, and monitoring of clearly defined complications of AP (10). Echosonography is usually done on the first day after hospital admission, and repeated as needed. It is the first, fundamental prognostic tool in the assessment of severity of AP (23). The method is capable of visualizing fluid collections, pseudocysts, necrotic collections or incapsulated necrosis. However, echosonography has its inherent limitations. Visualization of the pancreas can be difficult or impossible due to enlarged uterus and presence of excess intestinal gas, especially when a paralytic ileus develops in the first 48 hours $(24,25)$.

Endoultrasonography represents a combination of endoscopy and sonography and it is better in the detection of cholelithiasis if biliary pancreatitis is suspected. Endoscopic ultrasound is more specific than MRCP in the detection of choledocholithiasis and microlithiasis, and the method can be safely employed during the whole course of pregnancy (25).

Magnetic resonance (MR) is another visualization method which is valuable in the diagnosis of acute pancreatitis. Several clinical studies have shown that MR offers not only an adequate assessment of pancreatic parenchyma in mild AP, but also a reliable detection of pancreatic and peripancreatic necrosis, better discrimination between necrosis and fluid collections compared to $\mathrm{CT}$, obviating the need for radiation exposure and injections of potentially nephrotoxic contrast mediums. Nevertheless, the information is scarce as to the safety of MR in the first trimester of pregnancy because of possible thermal injury to the fetus $(25,26)$.

MR cholangiopancreatography (MRCP) enables pancreatic parenchyma evaluation and diagnosis of choledocholithiasis with the sensitivity of over $90 \%$, without any maternal and fetal exposure to harmful ionizing radiation. MRCP has limited the use of endoscopic retrograde cholangiopancreatography (ERCP) to exclusively therapeutic purposes $(26,27)$.

\section{Treatment}

Depending on the disease severity and course, the treatment can be conservative or surgical. These two modalities are not mutually exclusive; instead, they supplement each other. Treatment strategy involves an assessment of both maternal and fetal risks. The criteria for the treatment of pregnant women in intensive care units are similar to those for general population, such as the need for permanent fluid replacement, BMI $>30 \mathrm{~kg} / \mathrm{m}^{2}$, pleural effusions, C-reactive protein value of $>150 \mathrm{mg} / \mathrm{dL}$ in the first $48 \mathrm{~h}$, necrosis of over $30 \%$ of pancreatic tissue and $>3$ Ranson's criteria (28). Early ICU admission and adequate treatment reduces maternal morbidity and mortality rates.

During severe AP, when there is single or multiple organ failure, emergency childbirth may be necessary $(9,28)$. Termination of pregnancy is suggested if a clinical disease exacerbation occurs 24-48 hours after the initiation of active treatment for moderate and severe AP (29).

There have been no standardized recommendations for delivery for women with AP in their third trimester in order to reduce maternal and neonatal morbidity and mortality. The decision depends on the gestation age and severity of AP. Vaginal delivery, if feasible, is safer compared to cesarean section because of more limited chances for infection 
$(29,30)$. In the study by Luo et al., most deliveries have been performed by cesarean section (9).

Conservative treatment involves general therapeutic measures and management of complications.

General therapeutic measures are started by discontinuing food intake by mouth.

In patients with mild $A P$, oral food intake should be resumed after the cessation of pain (within 24-48 h), i.e. when painful abdominal tenderness has disappeared, but only if bowel peristalsis can be heard (31). Resumption of feeding per os is an important therapeutic measure in $A P$, providing the integrity of bowel mucosa and preventing the translocation of bowel bacteria and infection of necrotic areas $(19,31,32)$.

Fluid resuscitation is an essential and emergency measure in AP since it preserves pancreatic microcirculation and prevents necrosis (19). Furthermore, rapid fluid resuscitation is able to prevent hypotension and renal insufficiency. Adequacy of fluid resuscitation should be controlled by way of central venous pressure monitoring; clinically, the values of vital signs should be monitored, such as renal function, electrolytes and $\mathrm{HCT}$. Based on the available data, a conclusion may be drawn that the infusion speed of $5-10 \mathrm{ml} / \mathrm{kg}$ is safe if appropriate clinical parameters are monitored (magnitude of diuresis, heart beat rate).

Several studies have investigated the type of fluid to be used for fluid resuscitation. Most recent data has shown that Ringer's lactate solution is superior to physiological solutions in the prevention of SIRS $(28,30)$.

Analgesia has an important role in the management of pain in AP. A taering pain in severe AP is commonly the main therapeutic problem. It is most important to choose an effective and safe analgesic. Inadequate analgesia may increase patient anxiety and respiratory distress. On the other hand, analgesia may have an impact on the physiological response and immune mechanisms. In the treatment of $\mathrm{AP}$ in pregnancy, fentanyl and meperidine can be administered (28).

Antibiotics are not recommended in the prevention of pancreatic necrosis in AP. When their use in AP is justified, a special problem in pregnant women is the choice of antibiotic agents. If cholangitis is present or in infected pancreatic necrosis, the use of an appropriate antibiotic is required. Metronidazole passes the placental barrier, but recent studies have not reported any teratogenic effects of the drug (24). Imipenem belongs to the class of carbapenems and has a broad spectrum of activity. It is currently classified as a fetal risk category $\mathrm{C}$ drug. Although certain limited studies on animals have shown some adverse effects on fetus there are no appropriate studies on humans, so that possible benefits could perhaps outweigh potential risks (24). Quinolones too belong to the category $C$ drugs used in pregnancy. Ampicillin/sulbactam and piperacillin/ tazobactam are classified as category B (studies on animals demonstrating no risks, but the appropriate controlled studies on human subjects are missing).
Severe forms of AP are often accompanied by acidosis, which should be corrected with bicarbonates.

In pregnant women with severe hypertriglyceridemia heparin and insulin infusions can be used in order to enhance the activity of lipoprotein lipase (3). In some cases, plasmapheresis is recommended (33). However, plasmapheresis can be accompanied by complications such as transfusion and allergic reactions. Again, there are no standardized recommendations for such cases. Pregnancy termination (by labor induction or cesarean section) is considered and decided upon in accordance with the severity of AP. Early therapy in pregnant women with hypertriglyceridemia-related AP can improve the clinical course and outcome of the disease (33).

Low molecular weight heparin can reduce the incidence of pancreatic encephalopathy and mortality rates in severe acute pancreatitis cases in the general population (33).

ERCP should be done within 48-72 hours after the disease onset if $A P$ is complicated by acute cholangitis, when there are clinical or radiographic signs of gallstones present in the common bile duct (dilated bile duct, visible bile duct stone, jaundice, or permanently elevated liver enzyme values). The main problem with the procedure is harmful ionizing radiation. Nevertheless, some studies have shown that the dose of ionizing radiation can be reduced to the values markedly below the allowed values by using adequate lead shields for the pelvis and fetus and by shortening radiation exposure times, which involves adequate prior diagnosis using MRCP and EUS (24). ERCP is also useful in pregnant women in whom surgical intervention is not indicated. Endoscopic sphincterectomy is useful in the prevention of biliary AP recurrence during pregnancy.

\section{Surgical treatment}

During the course of AP treatment it is very important to make a timely decision about surgical treatment. It proceeds from the guidelines that in pancreatic necrosis, a surgical intervention is not recommended within 2 weeks of the disease onset, except in severe clinical exacerbations in spite of the measures of intense conservative treatment, in cases with infected pancreatic necrosis, or with multiorgan dysfunction in massive sterile necrosis (34).

\section{Conclusion}

Each pregnancy complicated by the development of AP is considered a high risk pregnancy, requiring a special treatment approach. Fortunately, AP in pregnancy is a rare entity. The existing limitations in diagnostic and therapeutic approach to pregnant women with AP require a serious multidisciplinary approach by gastroenterohepatologists, gynecologists and clinical pharmacologists. Larger clinical studies are required for the formulation of recommendations for the diagnosis, follow-up of the clinical course and treatment of $A P$ in pregnant women. 


\section{References}

1. Tang SJ, Rodriguez-Frias E, Singh S, Mayo MJ, Jazrawi SF, Sreenarasimhaiah J et al. Acute Pancreatitis During Pregnancy. Clin Gastroenterol Hepatol 2010;8(1):85-90. [CrossRef][PubMed]

2. Igbinosa O, Poddar S, Pitchumoni C. Pregnancy associated pancreatitis revisited. Clin Res Hepatol Gastroenterol 2013;37(2):177-81. [CrossRef][PubMed]

3. Mali P. Pancreatitis in pregnancy: etiology, diagnosis, treatment, and outcomes. Hepatobiliary Pancreat Dis Int 2016;15(4):434-8. [CrossRef] [PubMed]

4. Eddy JJ, Gideonsen MD, Song JY, Grobman WA, O'Halloran P. Pancreatitis in pregnancy. Obstet Ginecol 2008;112(5):1075-81. [CrossRef][PubMed]

5. Chibber T, Gibson PS. Fatal abdominal compartment syndrome due to severe triglyceride-induced pancreatitis in early pregnancy. J Obstet Gynaecol Can 2018; 40(5):609-13. [CrossRef][PubMed]

6. Hacker FM, Whalen PS, Lee VR, Caughey AB. Maternal and fetal outcomes of pancreatitis in pregnancy. Am J Obstet Gynecol 2015;213(4):568.e1-5. [CrossRef][PubMed]

7. Vilallonga R, Calero-Lillo A, Charco R, Balsells J. Acute pancreatitis during pregnancy, 7-year experience of a tertiary referral center. Cir Esp 2014;92(7):468-71. [CrossRef][PubMed]

8. Tang M, Xu JM, Song SS, Mei Q, Zhang $\amalg$. What may cause fetus loss from acute pancreatitis in pregnancy: Analysis of 54 cases. Medicine 2018;97(7):e9755. [CrossRef][PubMed]

9. Luo L, Zen $H, X u H$, Zhu Y, Liu P, Xia L, et al. Clinical characteristics of acute pancreatitis in pregnancy: experience based on 121 cases. Arch Gynecol Obstet 2018;297(2):333-9. [CrossRef][PubMed]

10. Hot S, Eğin S, Gökçek B, Yeşiltaş M, Karakaş DÖ. Acute biliary pancreatitis during pregnancy and in the post-delivery period. Ulus Travma Acil Cerrahi Derg 2019;25(3):253-8. [CrossRef][PubMed]

11. Crisan LS, Steidl ET, Rivera-Alsina ME. Acute hyperlipidemic pancreatitis in pregnancy. Am J Obstet Gynecol 2008;198(5):e57-9. [CrossRef][PubMed]

12. Avsar AF, Yildirim M, Cinkaya A. Unexpected fetal demise despite the reactive nonstress test during the conservative management of acute pancreatitis in pregnancy. Int Jl Surg Case Rep 2014;5(12):1047-9. [CrossRef][PubMed]

13. Bahat PY, Turan G, Cetin BA. Abruptio placentae caused by hypertriglyceridemia-induced acute pancreatitis during pregnancy: case report and literature review. Case Rep Obstet Gynecol 2018;2018: 3869695. [CrossRef][PubMed]

14. Ong $M$, Jerreat $L$, Hameed $A$. Familial hypertriglyceridaemia and type 2 diabetes in pregnancy: prevention of acutepancreatitis with diet control and omega-3 fatty acids. BMJ Case Rep 2019;12(5):e227321. [CrossRef][PubMed]

15. Lee CC, Chao AS, Chang YL, Peng HH, Wang TH, Chao A. Acute pancreatitis secondary to primary hyperparathyroidism in a postpartum patient: A case report and literature review. Taiwan J Obstet Gynecol 2014; 53(2):252-5. [CrossRef][PubMed]

16. Moldenhauer JS, O'Brien JM, Barton JR, Sibai B. Acute fatty liver of pregnancy associated with pancreatitis: a life-threatening complication. Am J Obstet Gynecol 2004;190(2):502-5. [CrossRef][PubMed]

17. Chan C, Mukerji M. Non-gallstone acute pancreatitis and pre-eclampsia: A case report. Case Rep Womens Health 2018;19:e00063. [CrossRef][PubMed]
18. Banks PA, Bollen TL, Dervenis C, Gooszen HG, Johnson CD, Sarr MG, et al. Classification of acute pancreatitis-2012: revision of the Atlanta classification and definitions by international consensus. Gut 2013; 62(1):102-11. [CrossRef][PubMed]

19. Waller A, Long B, Koyfman A, Gottlieb M. Acute pancreatitis: updates for emergency clinicians. J Emerg Med 2018;55(6):769-79. [CrossRef][PubMed]

20. Sun L, Li W, Sun F, Geng Y, Tong Z, Li J. Intraabdominal pressure in third trimester pregnancy complicated by acute pancreatitis: an observational study. BMC Pregnancy Childbirth 2015;15:223. [CrossRef][PubMed]

21. Ducarme G, Maire F, Chatel P, Luton D, Hammel P. Acute pancreatitis during pregnancy: a review. J Perinatol 2014;34(2):87-94. [CrossRef][PubMed]

22. Yang L, Zhao Z, Zhou K, Zhang Y. Acute hyperlipidemic pancreatitis accompanied by chylous ascites with normal amylase and lipase in pregnancy. J Clin Lipidol 2017;11(4):1091-4. [CrossRef][PubMed]

23. Kim JY, Jung SH, Choi HW, Song DJ, Jeong CY, Lee $\mathrm{DH}$, et al. Acute idiopathic pancreatitis in pregnancy: a case study. World J Gastroenterol 2014;20(43): 16364-7. [CrossRef][PubMed]

24. Pitchumoni CS, Yegneswaran B. Acute pancreatitis in pregnancy. World J Gastroenterol 2009;15(45):56416. [CrossRef][PubMed]

25. Roumieu F, Ponchon T, Audra P, Gaucherand P. Acute pancreatitis in pregnancy: place of the different explorations (magnetic resonance cholangiopancreatography, endoscopic ultrasonography) and their therapeutic consequences. Eur J Obstet Gynecol Reprod Biol 2008;140(1):141-2. [CrossRef][PubMed]

26. Levine D, Zuo C, Faro CB, Chen Q. Potential heating effect in the gravid uterus during MR HASTE imaging. J Magn Reson Imaging 2001;13(6):856-61. [CrossRef][PubMed]

27. Leyendecker JR, Gorengaut V, Brown JJ. MR imaging of maternal diseases of the abdomen and pelvis during pregnancy and the immediate postpartum period. Radiographics 2004;24(5):1301-16. [CrossRef][PubMed]

28. Pandey $R$, Jacob A, Brooks $H$. Acute pancreatitis in pregnancy: review of three cases and anaesthetic management. Int J Obstet Anesth 2012;21(4):360-3. [CrossRef][PubMed]

29. Sun Y, Fan C, Wang S. Clinical analysis of 16 patients with acute pancreatitis in the third trimester of pregnancy. Int J Clin Exp Pathol 2013;6(8):1696-701. [CrossRef][PubMed]

30. Ducarme G, Chatel P, Alves A, Hammel P, Luton D. Management of necrotizing pancreatitis in the third trimester of pregnancy. Arch Gynecol Obstet 2009; 279(4):561-3. [CrossRef][PubMed]

31. Zhao XL, Zhu SF, Xue GJ, Li J, Liu YL, Wan MH, et al. Early oral refeeding based on hunger in moderate and severe acute pancreatitis: A prospective controlled, randomized clinical trial. Nutrition 2015;31(1):171-5. [CrossRef][PubMed]

32. Wereszczynska-Siemiatkowska U, Swidnicka-Siergiejko A, Siemiatkowski A, Dabrowski A. Early enteral nutrition is superior to delayed enteral nutrition for the prevention of infected necrosis and mortality in acute pancreatitis. Pancreas 2013;42(4):640-6. [CrossRef][PubMed]

33. Huang C, Liu J, Lu Y, Fan J, Wang X, Liu J, et al. Clinical features and treatment of hypertriglyceri- 
demia-induced acute pancreatitis during pregnancy: a retrospective study. J Clin Apher 2016;31(6):571-8. [CrossRef][PubMed]
34. Robertson KW, Stewart IS, Imrie CW. Severe Acute Pancreatitis and Pregnancy. Pancreatology 2006;6(4): 309-15. [CrossRef][PubMed]

\title{
Revijalni rad
}

UDC: 616.37-002.1-092-08:618.2 doi: 10.5633/amm.2020.0306

\section{AKUTNI PANKREATITIS U TRUDNOĆI - OD ETIOPATOGENEZE DO TERAPIJE}

\author{
Snežana Tešić-Rajković1,2, Biljana Radovanović-Dinić1,2 \\ ${ }^{1}$ Univerzitet u Nišu, Medicinski fakultet, Niš, Srbija \\ ${ }^{2}$ Klinički centar Niš, Klinika za gastroenterologiju i hepatologiju, Niš, Srbija \\ Kontakt: Snežana Tešić-Rajković \\ Bulevar dr Zorana Đinđića 81, 18000 Niš, Srbija \\ E-mail: snezana.tesic.rajkovic@medfak.ni.ac.rs
}

Akutni pankreatitis (AP) u trudnoći je relativno retka bolest, ali istovremeno i veliki izazov za lekara, jer predstavlja potencijalnu pretnju po majku i plod. Pojava ove ozbiljne bolesti zahteva multidisciplinarni pristup u dijagnostici i lečenju, uz učešće ginekologa, gastroenterologa i hirurga. AP je učestaliji u trećem tromesečju i postpartalnom periodu. Trudnoća se dugo smatrala potencijalnim uzrokom akutnog pankreatitisa. Međutim, novija istraživanja ukazala su na prisustvo drugih etioloških faktora, kao što su kamenci ili hiperlipidemija, čime se objašnjava veća učestalost ove bolesti kod trudnica. Dijagnoza akutnog pankreatitisa u trudnoći može biti izazov za kliničara, jer kliničke manifestacije mogu nalikovati različitim komplikacijama u trudnoći, poput hiperemeze gravidarum, odvajanja posteljice ili rupture vanmaterične trudnoće. Strategija lečenja uključuje procenu rizika za majku i fetus. Tokom teškog AP, kada postoji insuficijencija jednog ili više organa, može biti potreban hitan porođaj. Ne postoje standardizovane preporuke za porođaj žena sa AP u trećem tromesečju, kako bi se umanjili morbiditet i smrtnost majki i novorođenčadi. Za formuliranje preporuka za dijagnozu, praćenje kliničkog toka bolesti i lečenja AP kod trudnica, potrebne su iscrpnije kliničke studije.

Acta Medica Medianae 2020;59(3):41-47.

KIjučne reči: pankreatitis, trudnoća, dijagnoza, terapija 